\title{
Assessment of Naturally Occurring Asbestos in the Area of Episcopia (Lucania, Southern Italy)
}

\author{
Andrea Bloise ${ }^{1, *} \mathbb{C}$, Claudia Ricchiuti ${ }^{2}$, Eugenia Giorno ${ }^{3}$, Ilaria Fuoco ${ }^{1}$, Patrizia Zumpano ${ }^{1}$, \\ Domenico Miriello $^{1}{ }^{\mathbb{D}}$, Carmine Apollaro $\left.{ }^{1} \mathbb{(}\right)$, Alessandra Crispini ${ }^{3}$, Rosanna De Rosa ${ }^{1}$ and \\ Rosalda Punturo ${ }^{2}$ \\ 1 Department of Biology, Ecology and Earth Sciences, University of Calabria, Via Pietro Bucci, I-87036 Rende, \\ Italy; ilaria.fuoco@unical.it (I.F.); patrizia85@gmail.com (P.Z.); miriello@unical.it (D.M.); \\ apollaro@unical.it (C.A.); derosa@unical.it (R.D.R.) \\ 2 Department of Biological, Geological and Environmental Sciences, University of Catania, Corso Italia, 55, \\ 95129 Catania CT, Italy; claudia.ricchiuti@unict.it (C.R.); punturo@unict.it (R.P.) \\ 3 MAT-InLAB-Department of Chemistry and Chemical Technologies, University of Calabria, \\ 87036 Arcavacata di Rende-Cosenza, Italy; eugenia.giorno@unical.it (E.G.); a.crispini@unical.it (A.C.) \\ * Correspondence: andrea.bloise@unical.it; Tel.: +39-0984-493588
}

Received: 5 April 2019; Accepted: 14 May 2019; Published: 16 May 2019

\begin{abstract}
Over the last few years, the risk to human health related to asbestos fiber exposure has been widely demonstrated by many studies. Serpentinites are the main rocks associated with naturally occurring asbestos (NOA). In order to investigate the presence of NOA, a mineralogical study was conducted on eleven serpentinite samples collected nearby the village of Episcopia (Lucania, Southern Italy). Various analytical techniques such as X-ray powder diffraction (XRPD), scanning electron microscopy combined with energy dispersive spectrometry (SEM-EDS) and derivative thermogravimetry (DTG) were used to determine the occurrence of asbestos minerals and to make morphological observations. Results pointed out that all of the samples contain asbestos minerals (e.g., tremolite, actinolite and chrysotile). Moreover, it was observed that both natural processes and human activity may disturb NOA-bearing outcrops and provoke the formation of potentially inhalable airborne dust causing the release of asbestos fibers into the environment, thereby increasing the risk to human health. For this reason, our study aims to highlight the requirement of a natural asbestos survey and periodic update in the area.
\end{abstract}

Keywords: naturally occurring asbestos; serpentinites; polymorphs; health hazard

\section{Introduction}

Today, it is widely accepted in the scientific community that exposure to asbestos bring to the development of negative health issues. Indeed, malignant mesothelioma and lung cancers could be caused by the inhalation of asbestos fibers due to environmental exposure [1-4].

The silicate mineral habitus type may be fibrous or non-fibrous and, among the minerals which form the airborne particulate, the most hazardous ones display a fibrous-asbestiform crystal habitus [5]. The term Naturally occurring asbestos (NOA) refers to asbestos minerals contained in rocks and soils to distinguishing them from those contained in asbestos containing materials (ACM) [6-10]. Six fibrous silicate minerals belonging to the serpentine (i.e., chrysotile) and amphibole (i.e., tremolite, actinolite, anthophyllite, amosite, and crocidolite) mineral groups are defined as asbestos by law in Europe and in several countries worldwide [5]. However, many studies demonstrate that besides these six varieties, which are regulated as potential environmental pollutants by law, asbestiform minerals such as erionite, antigorite and fluoro-edenite could also be dangerous if respired by humans, leading to 
several respiratory diseases [11-17]. The issue is even more complicated as the US National Institute for Occupational Safety and Health (NIOSH) has lately proposed to extend the definition of asbestos to all elongated mineral particles (EMP) [18].

Chrysotile is one of the three principal serpentine polymorphs (chrysotile, lizardite, and antigorite), and it occurs with a fibrous habit [17]. Structurally, it is constituted by tetrahedral silica-oxygen groups $\left(\mathrm{SiO}_{4}\right)(\mathrm{T})$ connected to brucite-type $\mathrm{Mg}(\mathrm{OH})_{2}$ octahedral sheets $(\mathrm{O})$ by sharing of oxygen atoms, forming structures having the ideal formula $\mathrm{Mg}_{3} \mathrm{Si}_{2} \mathrm{O}_{5}(\mathrm{OH})_{4}$ [17]. Because of the smaller dimension of the tetrahedral sheets to the corresponding octahedral ones, the connection of the TO layers results in a rolled papyrus-like microstructure which may compose a characteristic fibrous habit [18].

Amphiboles are built on double-chains of $\mathrm{Si}_{4} \mathrm{O}_{11}$ groups linked to each other by a variety of cations, which may display a fibrous habit being structurally elongated in one preferred crystal direction [17]. The chemical composition of the amphibole group can be expressed by the general formula $\mathrm{AB}_{2} \mathrm{C}_{5} \mathrm{~T}_{8} \mathrm{O}_{22}(\mathrm{OH})_{2}$, where $\mathrm{A}=\mathrm{Na}$ and $\mathrm{K} ; \mathrm{B}=\mathrm{Na}, \mathrm{Ca}, \mathrm{Fe}^{2+}, \mathrm{Mg}, \mathrm{Mn}^{2+}, \mathrm{Li}$ and rarer ions of similar size; $\mathrm{C}=\mathrm{Fe}^{2+}, \mathrm{Mg}, \mathrm{Mn}^{2+}, \mathrm{Li}, \mathrm{Fe}^{3+}, \mathrm{Cr}^{3+}, \mathrm{Al}, \mathrm{Mn}^{3+}, \mathrm{Zr}^{4+}$ and $\mathrm{Ti}^{4+} ; \mathrm{T}=\mathrm{Si}, \mathrm{Al}$, and $\mathrm{Ti}^{4+}$; and $\left(\mathrm{OH}^{-}\right)$ may be replaced by $\mathrm{F}^{-}, \mathrm{Cl}^{-}$and $\mathrm{O}^{2-}$ [17-21]. The A-site is in 10-12-fold coordination, while the $\mathrm{B}$ - and $\mathrm{C}$-sites are octahedrally coordinated [17]. Amphiboles can be shown in monoclinic or orthorhombic crystalline system, and for both, modern nomenclature is based on the atomic proportions of the major elements assigned to the A, B, C and T structural sites, following the rules of Leake $[19,20]$. Among the amphibole group minerals, tremolite, actinolite and anthophyllite occur in both asbestiform and non-asbestiform habit types, whereas crocidolite and amosite occur only in the asbestiform habit [18].

Serpentinite rocks are widely outcropping in the Lucania region (Southern Italy) [22,23] and often they are removed from their natural place of origin to be used as ornamental stones and building materials due to their coloring and physic-mechanical properties [24]. However, asbestos tremolite/actinolite and/or chrysotile are detected in serpentinite outcrops of several urban centers of the region [25], including Episcopia. The release of asbestos fibers in the environment is the result of both natural weathering processes (e.g., erosion) and human activities (e.g., excavation or road construction), which may disturb NOA outcrops and provoke the formation of potentially inhalable airborne dust [6,21], causing one or more respiratory diseases that could occur after a long latency time (e.g., [1]). In particular, about 3000 people living around the study area, comprising Episcopia village and its hamlets (Figure 1), could be exposed to potential sources of airborne asbestos due to the wide distribution of outcrops where serpentinite is exploited.

Previous studies on serpentine rocks, carried out in the central and southern parts of the Basilicata region, highlighted that it is necessary to deepen public health studies in order to characterize and determine the position of NOA [22-26]. Moreover, a recent epidemiological study conducted in twelve villages located in this part of the region showed significant excesses in health problems that are NOA-correlated cases [27]. Particularly, in the geographic area located about $20 \mathrm{~km}$ from Episcopia, several mesothelioma cases were documented in which the etiological factor turned out to be exposure to asbestos minerals $[28,29]$. Therefore, local maps indicating areas where asbestos is present in outcropping rocks, as is established by Italian law (DM 18/03/2003), are crucial to avoid hazardous exposure to populations.

So far, a detailed mineralogical characterization of asbestos minerals present in the area of the Episcopia village is still lacking in the literature. In this context, aiming to point out the eventual presence of asbestos minerals within the serpentinite rocks cropping out in the surroundings of the Episcopia village (Figure 1), we collected eleven rock samples, studied them and crossed the data obtained from different analytical techniques (i.e., X-ray powder diffraction (XRPD), scanning electron microscopy combined with energy dispersive spectrometry (SEM-EDS) and derivative thermogravimetry (DTG)) for a detailed mineralogical characterization. 

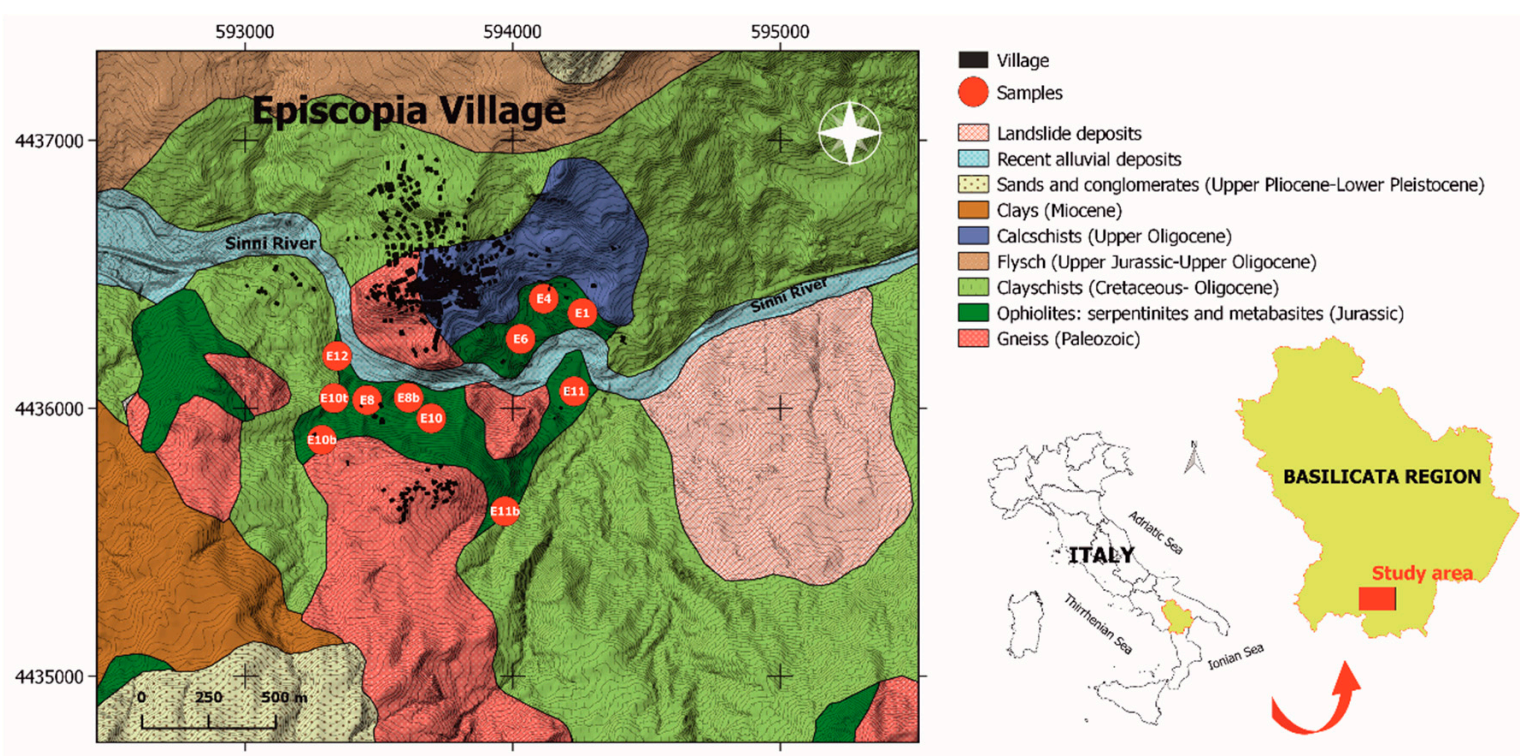

Figure 1. Simplified geological map of the Episcopia village and the study area location with the sample sites.

\section{Materials and Methods}

The Episcopia village (Figure 1) is located to the south-western part of the San Arcangelo basin in the Pollino National Park of the Basilicata region [30]. The pre-Pleistocene substrate (Episcopia-San Severino mélange) is discriminated by articulated tectonic slices overlapping that belong to different geological units and formations. Along the Sinni River, calc-schists and phyllites to the Unit of Frido crop out [31-35]. Over the Frido Unit, meta-ophiolites, made up of lenticular metabasite interbedded with and highly fractured serpentinites may occur (Figure 1) [32,36]. In a higher stratigraphic position, the Crete Nere and Saraceno formations and the Flysch of Albidona appear, which are non-metamorphic lithotypes referable to the North-Calabrian Unit [37].

With the aim to assess the presence of NOA in the area of the Episcopia village, 11 serpentinite rock samples were collected and characterized by X-ray powder diffraction (XRPD), scanning electron microscopy combined with energy dispersive spectrometry (SEM-EDS) and thermogravimetric analysis (TGA-DTG). Sample collection was conducted in the area surrounding the village, in particular the pieces were taken at the road cuts outside and within the village center and at dirt roads and slops in which serpentinites are well-exposed and display a vivid green color (Figure 2a,b).

$X$-ray powder diffraction (XRPD) data were obtained by X-ray diffraction acquired on a Bruker D2-Phaser (Bruker, Billerica, MA, USA) equipped with $\mathrm{Cu} \mathrm{K} \alpha$ radiation $(\lambda=1.5418 \AA$ ) and a Lynxeye detector, at $30 \mathrm{kV}$ and $10 \mathrm{~mA}$, with a step size of $0.01^{\circ}(2 \theta)$ and between 5 and $66^{\circ}(2 \theta)$. The crystalline phases and semi-quantitative mineralogical composition of samples were obtained using EVA software (DIFFRACPlusEVA), which compares the experimental peaks with the 2005 PDF2 reference patterns. In the laboratory, the samples were recovered under a binocular microscope (20x, ZEISS, Thornwood, NY, USA) in order to choose representative fragments (i.e., more fibrous) to be studied by scanning electron microscopy. Scanning electron microscopy analysis combined with energy dispersive spectrometry (SEM-EDS) for the morphological observations was performed using an Environmental Scanning Electron Microscope FEI QUANTA 200 (Thermo Fisher Scientific, Waltham, MA, USA) equipped with an X-ray EDS suite comprising a Si/Li crystal detector model EDAX-GENESIS4000 (EDAX Inc., Mahwah, NJ, USA). For SEM examinations, a piece of each sample was firmed on an SEM stub utilizing double-sided conductive adhesive tape. In the present paper, the weight change was evaluated by thermogravimetric analysis (TGA: Netzsch STA 449 C Jupiter, Netzsch-Gerätebau GmbH, Selb, Germany). During thermogravimetric analysis (TGA) the samples were heated at a rate of $10{ }^{\circ} \mathrm{C} \cdot \mathrm{min}^{-1}$ in the $30-850{ }^{\circ} \mathrm{C}$ temperature range under an air flow of $30 \mathrm{~mL} \cdot \mathrm{min}^{-1}$. About $20 \mathrm{mg}$ of a sample were 
used for each run. Instrumental precision was checked by three repeated collections on a kaolinite reference sample revealing good reproducibility (instrumental theoretical T precision of $\pm 1.2{ }^{\circ} \mathrm{C}$ ). Derivative thermogravimetry (DTG) was obtained using the Netzsch Proteus thermal analysis software (Netzsch-Gerätebau GmbH, Selb, Germany). For X-ray powder diffraction and thermal analysis investigations, samples were mechanically milled using a Bleuler Rotary Mill (Sepor, Los Angeles, CA, USA) for $10 \mathrm{~s}$ at a speed of 900 revolutions per min (rpm).
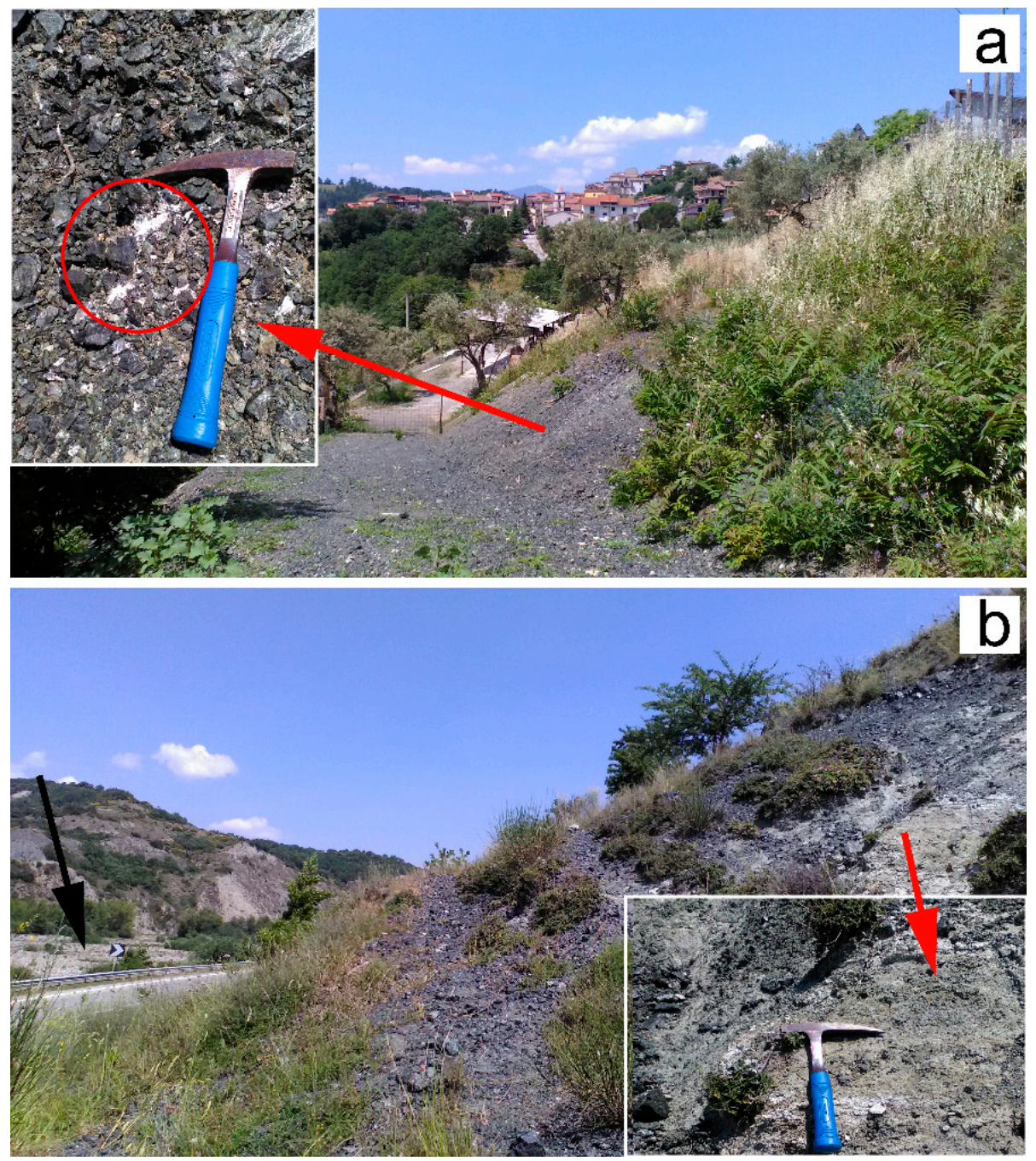

Figure 2. (a) Distant view of the Episcopia village, with appearance of serpentinite at the road cut near to the village (the red circle encloses white fibers of asbestos tremolite); and (b) pictures show vivid green serpentine at the road cut near to the village of Episcopia (highway 656 indicated by the black arrow). Inserts depict a zoomed-in area.

\section{Results and Discussion}

The field survey carried out nearby the Episcopia village (Figure 2) showed that serpentinite rocks appear to be characterized by a massive structure and by a dark-green color with widespread white parts consisting of fibrous minerals. Figure 3 shows the details of the studied samples at the mesoscopic scale, where it is possible to appreciate the appearance of white tremolite fibers (Figure 3a) and dark green serpentine (Figure $3 b$ ). 

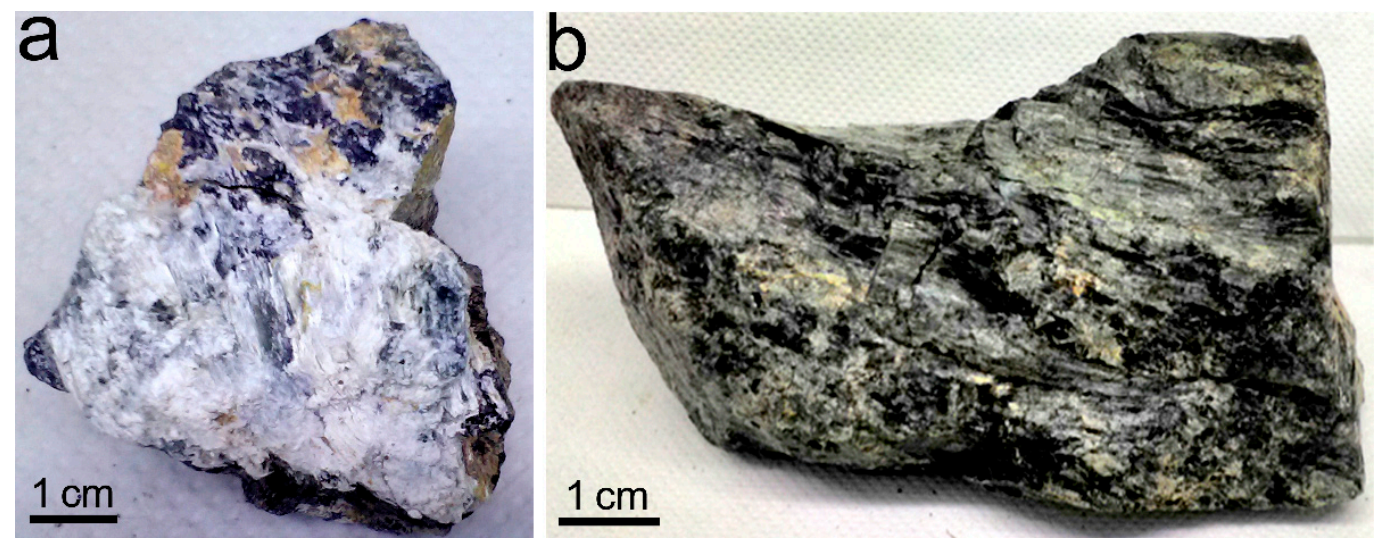

Figure 3. (a) White and silky tremolite on the surface of a serpentinite sample at the mesoscopic scale; and (b) the characteristic blazing surface of serpentinite, looking like a snake's skin.

The study conducted through various analytical techniques on eleven samples of serpentinite cropping out in the area of Episcopia village was finalized by determining the presence of NOA. Results of XRPD patterns showed that the investigated specimens are composed of serpentine minerals, chlorite, talc, tremolite, actinolite, willemseite and dolomite (Table 1). In particular, by the diffractograms interpretation the presence of serpentine minerals came out in all of the samples except for two, in which talc and tremolite (sample E10) and actinolite, willemseite, and dolomite (sample E10b) were the only phases detected. It is worth noting that the reflections diagnostic of the presence of asbestos amphiboles (i.e., tremolite/actinolite) were found in eight samples out of eleven (Table 1).

Table 1. Semi-quantitative mineralogical composition of samples in order of decreasing relative abundance, detected by X-ray powder diffraction (XRPD), scanning electron microscopy combined with energy dispersive spectrometry (SEM-EDS) and derivative thermogravimetry (DTG) analysis. Atg = antigorite, $\mathrm{Lz}=$ lizardite, $\mathrm{Ctl}=$ chrysotile, $\mathrm{Act}=$ asbestos actinolite, $\mathrm{Tr}=$ asbestos tremolite, $\mathrm{PS}=$ polygonal serpentine, $\mathrm{Chl}=$ chlorite, $\mathrm{Will}=$ willemseite, $\mathrm{Dol}=$ dolomite , and Tlc $=$ talc. Mineral symbols after [38].

\begin{tabular}{ccccc}
\hline Sample & $\begin{array}{c}\text { Site } \\
\text { Description }\end{array}$ & $\begin{array}{c}\text { Longitude East } \\
\text { (WGS8) }\end{array}$ & $\begin{array}{c}\text { Latitude North } \\
\text { (WGS84) }\end{array}$ & $\begin{array}{c}\text { Phases Detected } \\
\text { Max } \leftrightarrow \text { Min }\end{array}$ \\
\hline E1 & Slope & 594261 & 4436353 & Ctl $>$ Liz $>$ Atg $>$ Chl $>$ Tlc $>$ Tr \\
Et $>$ PS $>$ Chl $>$ Tlc $>$ Tr \\
E6 & Road cut & 594118 & 4436407 & Chl $>$ Tr $>$ Liz $>$ Ctl \\
E8 & Slope & 594031 & 4436259 & Chl $>$ Liz $>$ Ctl \\
E8b & Dirt road & 593457 & 4436029 & Chl $>$ Ctl $>$ PS \\
E10 & Slope & 593611 & 4436038 & Tlc $>$ Tr \\
E10b & Road cut & 593287 & 4435960 & Wil $>$ Dol $>$ Act \\
E10t & Dirt road & 593332 & 4435880 & Tlc $>$ Ctl $>$ Atg $>$ Act \\
E11 & Road cut & 594231 & 4436037 & Tlc $>$ Liz $>$ Ctl, \\
E11b & Road cut & 593973 & 4436063 & Liz $>$ Ctl $>$ Tlc $>$ Tr \\
E12 & Road cut & 593342 & 443615 & Tlc $>$ Ctl $>$ PS $>$ Act \\
\hline
\end{tabular}

However, discrimination among the serpentine varieties (i.e., chrysotile, lizardite, antigorite, and polygonal serpentine) was not achievable by using only the X-ray powder diffraction method because diffraction peaks of the serpentine polymorphs overlap each other [7]. As reported in the literature, thermal analysis allowed for the discrimination among serpentine varieties [22,39]. Therefore, only samples in which serpentine minerals were detected by XRPD have been further investigated by thermal analysis. The correspondence between the maximum loss rates peaks and the serpentine minerals was defined in agreement with the literature data [40]. 
In particular, DTG curves showed the maximum peaks loss rate in the temperature range of $605-690{ }^{\circ} \mathrm{C}$ due to the chrysotile breakdown (Figure 4). The presence of DTG peaks in a temperature range of $705-731^{\circ} \mathrm{C}$ were related to lizardite dehydroxylation, while antigorite occurred at higher temperatures (a $770{ }^{\circ} \mathrm{C}$ average value) than lizardite. Based on thermal analysis, chrysotile was identified in nine out of eleven analyzed samples, lizardite was detected in five samples, while antigorite and polygonal serpentine in two and three samples, respectively (Table 1).

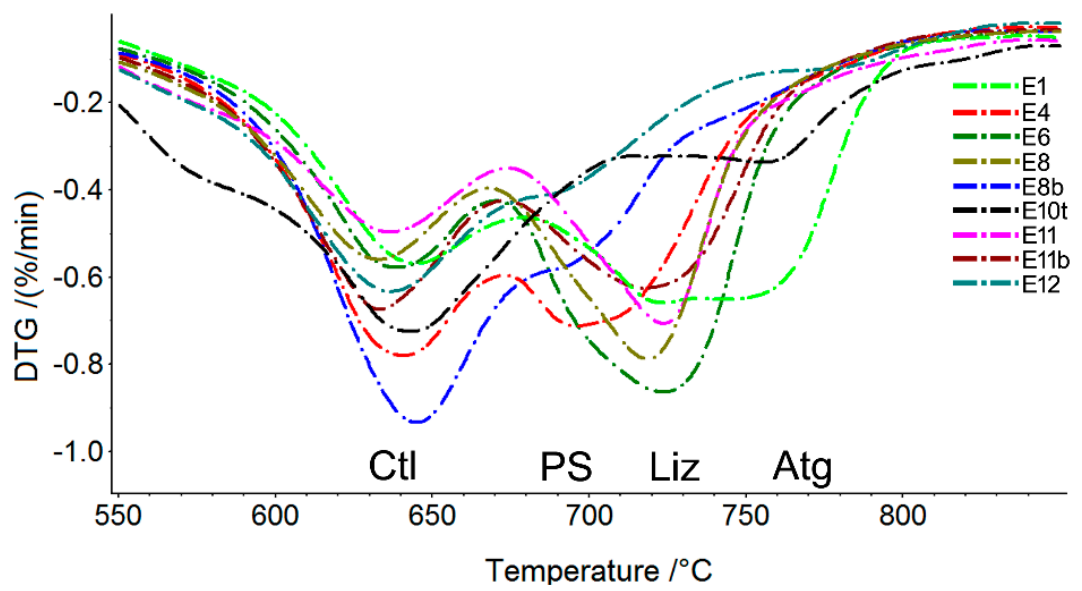

Figure 4. DTG curves for each sample in the temperature range of 500-850 ${ }^{\circ} \mathrm{C}$. Endothermic peaks related to $\mathrm{Ctl}=$ chrysotile, $\mathrm{PS}=$ polygonal serpentine, $\mathrm{Liz}=$ lizardite, and Atg = antigorite. Mineral symbols after [38].

SEM observations highlighted that chrysotile is made up of either thin and flexible isolated fibril (Figure 5a) with a length longer than 6-8 $\mu \mathrm{m}$ or crystals arranged in bundles. In contrast, tremolite and actinolite appear straight and show a slender needle-like crystal habit with a length longer than $10 \mu \mathrm{m}$ (Figure 5b). It is worth remembering that fibers are composed of many fibrils, which tend to split up along the fiber elongation axis [18]. This tendency leads to even smaller diameters, thus increasing the risks for human health related to the inhalation when they become airborne. Moreover, fibers having size matching with those of regulated asbestos (length $>5 \mu \mathrm{m}$ and an aspect ratio of 3 ) of both chrysotile and tremolite/actinolite have been detected in all samples, even if the length of both chrysotile and tremolite/actinolite fibers were sometimes shorter than the length established by law (Italian Legislative Decree 277/9).
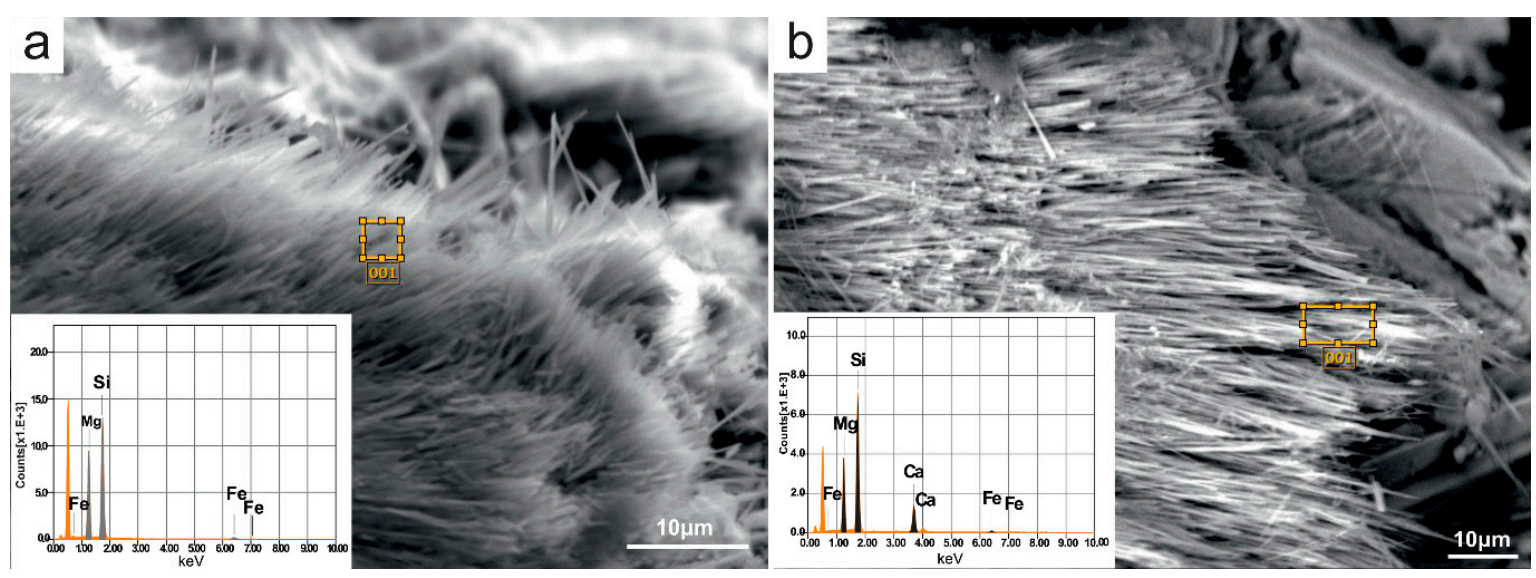

Figure 5. Scanning electron microscopy (SEM) images of asbestos. (a) Chrysotile sample E11; and (b) tremolite sample E4. Graphical inserts depict energy dispersive spectrometry (EDS) point analysis. 
The use of the energy dispersive spectrometry (EDS) spot analysis (Figure $5 \mathrm{a}, \mathrm{b}$ inserts) is essential for the correct identification of the chrysotile and tremolite/actinolite asbestos fibers. Chrysotile fibers show low amounts of $\mathrm{Al}$, which mainly replaces the $\mathrm{Mg}$ in the octahedral sites. The EDS analyses revealed a low percent replacement of $\mathrm{Mg}$ for Fe occurs in the octahedral sites of chrysotile [22]. Regarding iron content, it ranges from a minimum of $3.51 \mathrm{wt} \%$ (sample E11) of FeO to $8.71 \mathrm{wt} \%$ (sample E12) with an mean value of $4.90 \mathrm{wt} \%$. The presence of iron could play an significant function in the biological-mineral system interaction, increasing fiber toxicity, which has been unequivocally related to the effect of surface iron ions acting as catalytic sites generating free radicals and reactive oxygen species (ROS) [41].

The chemical composition of amphiboles detected by EDS was plotted in the diagram Si vs. $\mathrm{Mg} /\left(\mathrm{Mg}+\mathrm{Fe}^{2+}\right)[19]$, and graphically reported in Figure 6. Three samples (E10b, E10t, and E12) were plotted in the field of actinolite since their composition is: (i) an Si value to 7.94 a.p.f.u. (atoms per formula unit) and $\mathrm{Mg} /\left(\mathrm{Mg}+\mathrm{Fe}^{2+}\right)$ value to 0.87 (sample E10t); (ii) an Si value to 7.96 a.p.f.u. and $\mathrm{Mg} /\left(\mathrm{Mg}+\mathrm{Fe}^{2+}\right.$ ) value to 0.88 (sample E10b); and (iii) an Si value to 7.98 a.p.f.u. and $\mathrm{Mg} /\left(\mathrm{Mg}+\mathrm{Fe}^{2+}\right)$ value equal to 0.89 . Five amphiboles were classified as tremolite (Table 1) since their chemical composition is: an Si range from 7.94 to 7.99 a.p.f.u. and a $\mathrm{Mg} /\left(\mathrm{Mg}+\mathrm{Fe}^{2+}\right)$ value $>0.9$.

The presence of iron in actinolite and tremolite could have a preeminent role in the biological-mineral system interaction. Indeed, it is worth pointing out that many researchers suggested that iron is a key component in asbestos toxicity [41-43]. Although some authors consider amphiboles (e.g., tremolite and crocidolite) to be more harmful than chrysotile to human health $[43,44]$, all of the six asbestos minerals are assumed to be harmful. Therefore, in our opinion serpentinite samples containing asbestos are all potentially toxic for humans.

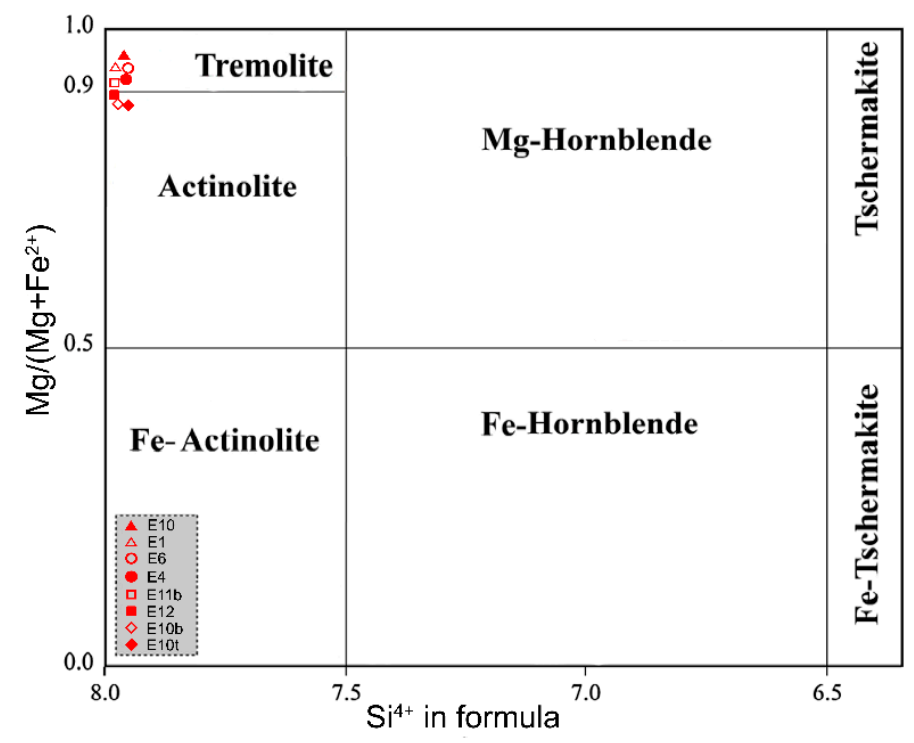

Figure 6. Amphibole classification diagram (after [19]).

Moreover, the analyses carried out by means of XRPD permitted also the identification of a nickelian-talc type named willemseite $(\mathrm{Ni}, \mathrm{Mg})_{3} \mathrm{Si}_{4} \mathrm{O}_{10}(\mathrm{OH})_{2}$ never detected before in the study area (Table 1). Table 1 shows the list of the phases identified in each sample and chrysotile, tremolite and actinolite turn out to be common phases of the serpentinite rocks studied. Since the economy of the area is mainly based on sheep farming and agriculture, it may be assessed that shepherds and farmers are the working figures potentially at highest risk of exposure. The continuous movements of the flocks and the machining of the soil could cause suspension and diffusion of powders containing chrysotile, tremolite and actinolite fibers, with the consequent risk of inhalation by people employed in these activities. A similar situation could occur for farmers who, meanwhile carrying out their business, can breathe dangerous chrysotile, tremolite and actinolite fibers. Furthermore, other figures can suffer 
damage as a result of exposure to asbestos dust that is freed during the construction of rural buildings (for example houses) or other construction works (e.g., dirt roads and fences). Moreover, due to its geomorphological, geological and climatic setting, the Basilicata region (Figure 1) is affected by the diffuse presence of landslides [45] that may disturb NOA-bearing outcrops. Indeed, chrysotile together with asbestos tremolite and actinolite may release airborne dust in the neighboring environment, thus increasing population exposure to hazardous air fibers.

\section{Conclusions}

In this study, serpentinite rocks cropping out nearby the Episcopia village (Lucania, Southern Italy) have been investigated by means of various analytical techniques (i.e., XRPD, SEM-EDS and DTG) with the aim to assess the occurrence of naturally occurring asbestos. The results obtained indicate that the presence of asbestos was detected in all the serpentinite samples, and therefore it may be deduced that all of the analyzed specimens are potentially injurious to human health.

The presence of chrysotile was detected in nine of the eleven samples analyzed, while asbestos tremolite and asbestos actinolite were identified in five and three samples, respectively. The observed dimension of these fibers generally matched with the size of regulated asbestos. Weathering processes and/or human activities are able to produce dust containing asbestos fibers which are potentially inhalable, therefore increasing the human health risks. Their wide dispersion into the environment makes inhalation a risk even for those people not related to occupational purposes. The presence of NOA during working activities should be considered in the preliminary planning step to avoid workers' health risks and sanitary risks for the population living near asbestos sites. The disturbance (excavations, remediation, and moving) of asbestos potentially containing rocks and soils should be foreseen and planned so that adequate control measures may be carried out to avoid the spreading of airborne asbestos dust during work.

It is worth mentioning that, owing to possible health problems due to asbestos fiber dispersion the Italian law regulates these types of outcrops, demanding the asbestos presence identification in order to increase health safeguard. These new knowledge and highlights can be used to provide data for compulsory Italian mapping and should encourage local, regional and national authorities to avoid and to prevent asbestos exposure risks. Moreover, this study could be useful to make the population aware of the geological context in which they live, in order to take adequate prevention measures and good practices in everyday life. Therefore, the asbestos minerals investigation is essential from both scientific and legislative viewpoint, particularly for the administrative agencies, whose task it is to defense public health and to implement construction and safeguard policies.

Author Contributions: Conceptualization, A.B. and R.P.; methodology, A.B. and E.G.; software, A.B.; validation, A.B., R.P. and C.R.; formal analysis, A.B. and P.Z.; investigation, A.B., C.R. and R.P.; resources, A.B. and R.P.; data curation, A.B. C.R. and R.P.; writing - original draft preparation, A.B., C.R. and R.P.; writing—review and editing, A.B., C.R., R.P., P.Z., I.F., D.M., C.A., E.G., A.C. and R.D.R.; visualization, A.B.; supervision, A.B. and R.P.; project administration, A.B. and R.P.; and funding acquisition, A.B. and R.P.

Funding: The work has received financial support from the FFABR fund (by the Italian MIUR) scientific responsible Andrea Bloise. Part of this research was carried out under the financial support of "Piano Triennale della Ricerca (2017-2020)" (Università di Catania, Dipartimento di Scienze Biologiche, Geologiche e Ambientali), scientific responsible Rosalda Punturo.

Acknowledgments: The authors thank E. Barrese for the support during data collection. The work has received financial support from University of Calabria and University of Catania.

Conflicts of Interest: The authors declare no conflict of interest.

\section{References}

1. Baumann, F.; Buck, B.J.; Metcalf, R.V.; McLaurin, B.T.; Merkler, D.J.; Carbone, M. The presence of asbestos in the natural environment is likely related to mesothelioma in young individuals and women from Southern Nevada. J. Thorac. Oncol. 2015, 10, 731-737. [CrossRef] [PubMed] 
2. Gamble, J.F.; Gibbs, G.W. An evaluation of the risks of lung cancer and mesothelioma from exposure to amphibole cleavage fragment. Regul. Toxicol. Pharmacol. 2008, 52, 154-186. [CrossRef]

3. Hillerdal, G. Mesothelioma: Cases associated with non-occupational and low dose exposures. Int. J. Occup. Environ. Med. 1999, 56, 505-513. [CrossRef]

4. Berry, G.; Gibbs, G.W. Mesothelioma and asbestos. Regul. Toxicol. Pharmacol. 2008, 52, S223-S231.

5. Gualtieri, A.F. Mineral Fibers: Crystalchemistry, Chemical-Physical Properties, Biological Interaction and Toxicity; European Mineralogical Union and Mineralogical Society of Great Britain and Ireland: London, UK, 2017; p. 533.

6. Punturo, R.; Bloise, A.; Critelli, T.; Catalano, M.; Fazio, E.; Apollaro, C. Environmental implications related to natural asbestos occurrences in the ophiolites of the Gimigliano-Mount Reventino Unit (Calabria, southern Italy). Int. J. Environ. Res. 2015, 9, 405-418.

7. Bloise, A.; Punturo, R.; Catalano, M.; Miriello, D.; Cirrincione, R. Naturally occurring asbestos (NOA) in rock and soil and relation with human activities: The monitoring example of selected sites in Calabria (southern Italy). Ital. J. Geosci. 2016, 135, 268-279. [CrossRef]

8. Vignaroli, G.; Ballirano, P.; Belardi, G.; Rossetti, F. Asbestos fibre identification vs. evaluation of asbestos hazard in ophiolitic rock mélanges, a case study from the Ligurian Alps (Italy). Environ. Earth Sci. 2014, 72, 3679-3698. [CrossRef]

9. Bloise, A.; Belluso, E.; Critelli, T.; Catalano, M.; Apollaro, C.; Miriello, D.; Barrese, E. Amphibole asbestos and other fibrous minerals in the meta-basalt of the Gimigliano-Mount Reventino Unit (Calabria, south-Italy). Rend. Online Soc. Geol. Ital. 2012, 21, 847-848.

10. Harper, M. 10th Anniversary critical review: Naturally occurring asbestos. J. Environ. Monit. 2008, 10, 1394-1408. [CrossRef] [PubMed]

11. Baumann, F.; Ambrosi, J.-P.; Carbone, M. Asbestos is not just asbestos: An unrecognised health hazard. Lancet Oncol. 2013, 14, 576-578. [CrossRef]

12. Ballirano, P.; Bloise, A.; Cremisini, C.; Nardi, E.; Montereali, M.R.; Pacella, A. Thermally induced behavior of the K-exchanged erionite: A further step in understanding the structural modifications of the erionite group upon heating. Period. Mineral. 2018, 87, 123-134.

13. Ballirano, P.; Pacella, A.; Bloise, A.; Giordani, M.; Mattioli, M. Thermal Stability of Woolly Erionite-K and Considerations about the Heat-Induced Behaviour of the Erionite Group. Minerals 2018, 8, 28. [CrossRef]

14. Cardile, V.; Lombardo, L.; Belluso, E.; Panico, A.; Capella, S.; Balazy, M. Toxicity and carcinogenicity mechanisms of fibrous antigorite. Int. J. Environ. Res. Public Health 2007, 4, 1-9. [CrossRef] [PubMed]

15. Pinizzotto, M.R.; Cantaro, C.; Caruso, M.; Chiarenza, L.; Petralia, C.; Turrisi, S.; Brancato, A. Environmental monitoring of airborne fluoro-edenite fibrous amphibole in Biancavilla (Sicily, Italy): A nine-years survey. J. Mediterr. Earth Sci. 2018, 10, 89-95. [CrossRef]

16. Bellomo, D.; Gargano, C.; Guercio, A.; Punturo, R.; Rimoldi, B. Workers' risks in asbestos contaminated natural sites. J. Mediterr. Earth Sci. 2018, 10, 97-106.

17. Ballirano, P.; Bloise, A.; Gualtieri, A.F.; Lezzerini, M.; Pacella, A.; Perchiazzi, N.; Dogan, M.; Dogan, A.U. The Crystal Structure of Mineral Fibers. In Mineral Fibers: Crystal Chemistry, Chemical-Physical Properties, Biological Interaction and Toxicity; Gualtieri, A.F., Ed.; European Mineralogical Union: London, UK, 2017; Volume 18, pp. 17-53.

18. Belluso, E.; Cavallo, A.; Halterman, D. Crystal habit of mineral fibres. In Mineral Fibres: Crystal Chemistry, Chemical-Physical Properties, Biological Interaction and Toxicity; Gualtieri, A.F., Ed.; European Mineralogical Union: London, UK, 2017; Volume 18, pp. 65-109.

19. Leake, B.E.; Woolley, A.R.; Arps, C.E.; Birch, W.D.; Gilbert, M.C.; Grice, J.D.; Linthout, K.; Laird, J.; Mandarino, J.; Maresch, W.V.; et al. Nomenclature of amphiboles: Report of the subcommittee on amphiboles of the international mineralogical association, commission on new minerals and mineral names. Can. Mineral. 1997, 35, 219-246.

20. Bloise, A.; Fornero, E.; Belluso, E.; Barrese, E.; Rinaudo, C. Synthesis and characterization of tremolite asbestos fibres. Eur. J. Mineral. 2008, 20, 1027-1033. [CrossRef]

21. Bloise, A.; Barca, D.; Gualtieri, A.F.; Pollastri, S.; Belluso, E. Trace elements in hazardous mineral fibres. Environ. Pollut. 2016, 216, 314-323. [CrossRef] 
22. Bloise, A.; Catalano, M.; Critelli, T.; Apollaro, C.; Miriello, D. Naturally occurring asbestos: Potential for human exposure, San Severino Lucano (Basilicata, Southern Italy). Environ. Earth Sci. 2017, 76, 648. [CrossRef]

23. Punturo, R.; Ricchiuti, C.; Bloise, A. Assessment of Serpentine Group Minerals in Soils: A Case Study from the Village of San Severino Lucano (Basilicata, Southern Italy). Fibers 2019, 7, 18. [CrossRef]

24. Dichicco, M.C.; Paternoster, M.; Rizzo, G.; Sinisi, R. Mineralogical Asbestos Assessment in the Southern Apennines (Italy): A Review. Fibers 2019, 7, 24. [CrossRef]

25. Massaro, T.; Baldassarre, A.; Pinca, A.; Martina, G.L.; Fiore, S.; Lettino, A.; Cassano, F.; Musti, M. Exposure to asbestos in buildings in areas of Basilicata characterized by the presence of rocks containing tremolite. G. Ital. Med. Lav. Ergon. 2012, 34 (Suppl. 3), 568-570.

26. Dichicco, M.C.; Laurita, S.; Paternoster, M.; Rizzo, G.; Sinisi, R.; Mongelli, G. Serpentinite Carbonation for $\mathrm{CO}_{2}$ Sequestration in the Southern Apennines: Preliminary Study. Energy Procedia 2015, 76, 477-486. [CrossRef]

27. Caputo, A.; De Santis, M.; Manno, V.; Cauzillo, G.; Bruni, B.M.; Palumbo, L.; Conti, S.; Comba, P. Health impact of asbestos fibres naturally occurring in Mount Pollino area (Basilicata Region, Southern Italy). Epidemiol. Prev. 2018, 42, 142-150. [PubMed]

28. Pasetto, R.; Bruni, B.; Bruno, C.; Cauzillo, G.; Cavone, D.; Convertini, L.; De Mei, B.; Marconi, A.; Montagano, G.; Musti, M.; et al. Mesotelioma pleurico ed esposizione ambientale a fibre minerali: Il caso di un'area rurale in Basilicata. Annali dell'Istituto Superiore di Sanità 2004, 40, 251-265. [PubMed]

29. Musti, M.; Bruno, C.; Cassano, F.; Caputo, A.; Cauzillo, G.; Cavone, D.; Convertini, L.; De Blasio, A.; De Mei, B.; Marra, M.; et al. Sorve-glianza sanitaria delle popolazioni esposte a fibre di tremolite nel territorio della ASL 3-Lagonegro (PZ). Annali dell'Istituto Superiore di Sanità 2006, 42, 469-476. [PubMed]

30. Pieri, P.; Vitale, G.; Beneduce, P.; Doglioni, C.; Gallicchio, S.; Giano, S.I.; Loizzo, R.; Moretti, M.; Prosser, G.; Sabato, L.; et al. Tettonica quaternaria nell'area bradanico-ionica. Il Quaternario 1997, 10, 535-542.

31. Critelli, S.; Le Pera, E. Post-Oligocene sediment dispersal systems and unroofing history of the Calabrian Microplate, Italy. Int. Geol. Rev. 1998, 48, 609-637. [CrossRef]

32. Vitale, S.; Ciarcia, S.; Tramparulo, F.D.A. Deformation and stratigraphic evolution of the Ligurian Accretionary Complex in the southern Apennines (Italy). J. Geodyn. 2013, 66, 120-133. [CrossRef]

33. Apollaro, C.; Dotsika, E.; Marini, L.; Barca, D.; Bloise, A.; De Rosa, R.; Doveri, M.; Lelli, M.; Muto, F. Chemical and isotopic characterization of the thermo mineral water of Terme Sibarite springs (Northern Calabria, Italy). Geochem. J. 2012, 46, 117-129. [CrossRef]

34. Guagliardi, I.; Buttafuoco, G.; Apollaro, C.; Bloise, A.; De Rosa, R.; Cicchella, D. Using gamma-ray spectrometry and geostatistics for assessing geochemical behavior of radioactive elements in the Lese catchment (southern Italy). Int. J. Environ. Res. 2013, 7, 645-658.

35. Apollaro, C.; Fuoco, I.; Brozzo, G.; De Rosa, R. Release and fate of Cr (VI) in the ophiolitic aquifers of Italy: The role of $\mathrm{Fe}$ (III) as a potential oxidant of $\mathrm{Cr}$ (III) supported by reaction path modelling. Sci. Total Environ. 2019, 660, 1459-1471. [CrossRef]

36. Bonardi, G.; Amore, F.O.; Ciampo, G.; Capoa, P.; Miconnet, P.; Perrone, V. Il Complesso Liguride Auct.: Stato delle conoscenze e problemi aperti sulla sua evoluzione pre-appenninica ed i suoi rapporti con l'Arco Calabro. Mem. Soc. Geol. Ital. 1988, 41, 17-35.

37. Belviso, C.; Lettino, A.; Cavalcante, F.; Fiore, S.; Finizio, F. Carta Geologica delle Unità Liguridi dell'area del Pollino (Basilicata); Digilabs: Bari, Italy, 2009; ISBN 978-88-7522-026-6.

38. Whitney, D.L.; Evans, B.W. Abbreviations for names of rock-forming minerals. Am. Mineral. 2010, 95, 185-187. [CrossRef]

39. Bloise, A.; Kusiorowski, R.; Lassinantti Gualtieri, M.; Gualtieri, A.F. Thermal behaviour of mineral fibers. In Mineral Fibers: Crystal Chemistry, Chemical-Physical Properties, Biological Interaction and Toxicity; Gualtieri, A.F., Ed.; European Mineralogical Union: London, UK, 2017; Volume 18, pp. 215-252.

40. Viti, C. Serpentine minerals discrimination by thermal analysis. Am. Mineral. 2010, 95, 631-638. [CrossRef]

41. Fubini, B.; Mollo, L. Role of iron in the reactivity of mineral fibers. Toxicol. Lett. 1995, 82, 951-960. [CrossRef]

42. Shukla, A.; Mossman, B. Cell signalling and transcription factor activation by asbestos in lung injury and disease. Int. J. Biochem. Cell Biol. 2003, 35, 1198-1209. [CrossRef] 
43. Turci, F.; Tomatis, M.; Pacella, A. Surface and bulk properties of mineral fibres relevant to toxicity. In Mineral Fibers: Crystal Chemistry, Chemical-Physical Properties, Biological Interaction and Toxicity; Gualtier, A.F., Ed.; European Mineralogical Union: London, UK, 2017; Volume 18, pp. 171-214.

44. Oze, C.; Solt, K. Biodurability of chrysotile and tremolite asbestos in simulated lung and gastric fluid. Am. Mineral. 2010, 95, 825-831. [CrossRef]

45. Lazzari, M.; Piccarreta, M.; Capolongo, D. Landslide triggering and local rainfall thresholds in Bradanic Foredeep, Basilicata region (southern Italy). In Landslide Science and Practice; Springer: Berlin/Heidelberg, Germany, 2013; pp. 671-677.

(C) 2019 by the authors. Licensee MDPI, Basel, Switzerland. This article is an open access article distributed under the terms and conditions of the Creative Commons Attribution (CC BY) license (http://creativecommons.org/licenses/by/4.0/). 